\title{
젠더기반 국제개발협력과 인권
}

목 차

I. 들어가며

II. 젠더와 개발

1. 젠더의 이해

2. 개발에 있어서 젠더의 중요성

3. 젠더와 개발논의의 변천

III. 성평등의 국제적 기준 확립

1. 베이징 행동강령

2. 여성차별철폐협약

3. 사회권규약 상의 인권과 성평등

4. 기타 주요 UN회의 합의문서들

5. 안보리 결의 1325 호

IV. 성평등 달성을 위한 전략: 성 주류화
1. 성 주류화란?
2. 성 주류화의 분석 틀
3. 성 주류화에서 고려해야 할 기본 문제들

V. 젠더기반 국제개발협력을 통한 여성인권 강화

1. MDGs에서 SDGs로의 이행

2. SDGs와 목표 5 성평등, 세부목표

3. 젠더기반 개발협력의 실제: KOICA 사업을 중심으로

4. 결론에 대신하여: 앞으로의 과제

\section{참고문헌}




\section{요 약}

2015년 국제연합(United Nations, 이하 UN)이 채택한 지속가능개발목표(Sustainable Development Goals, 이하 SDGs)는 2030년까지 달성해야 할 목표들 중 하나로 '성평등 (gender equality)'을 포함하고 있다. 동시에 '성평등'은 모든 다른 16 개의 개발목표에 주류화되어야 할 것이 요구된다.

개발협력에 있어 젠더란 무엇인가? SDGs를 달성하기 위한 국제개발협력에 젠더가 왜 중요한가? 성 주류화는 무슨 의미이고, 어떻게 하는 것인가? 또한, 성평등이 목표로 설정되기까지 어떤 국제적 논의가 있었는지 그 맥을 짚어봄으로써 성평등의 기준이 무엇인지 살펴본다. 베이징 행동강령, 여성차별철폐협약 등 기본 인권문서들을 소개하 고, 성평등을 달성하기 위한 전략으로 채택된 성 주류화의 내용도 간단히 논의한다. 또한, SDGs의 각 목표에 젠더가 어떻게 관련되어 있는지 세부목표들을 살펴본다.

젠더기반 국제개발협력을 보다 잘 이해할 수 있도록 한국국제협력단이 수행하고 평가가 끝난 12 개 개발협력사업을 분석하여 과연 범분야로 주류화하게 되어있는 젠더 측면이 제대로 이루어지고 있는지 살펴보고, 효과적인 젠더기반 개발협력을 위한 실천적 과제도 제시하였다.

주제어 : 젠더와 개발협력, 성평등, 성 주류화, 지속가능개발목표, gender and development 


\section{I. 들어가며}

성평등(gender equality)은 현재 세계 각국이 추구하고 있는 중요한 목표로서 SDGs 17 개

목표 중 독자목표로 $\mathrm{SDG} 5$ 가 설정되었다. 그리고 동시에 성평등은 모든 분야를 관통하는 범분야 이슈로 선언되었다(UN, 2015: 문단 20).1) 이는 빈곤 퇴치, 건강증진, 안전한 식수 확보 등 개발협력의 모든 분야에 젠더관점이 통합되어야 함을 뜻한다. 개발협력에서 젠더가 갖는 중요성은 여성의 인권 자체를 위해서 뿐만 아니라 성공적인 개발협력을 위해서도 필수적이다.

이 글에서는 젠더와 개발의 상관관계, 성평등을 성취하기 위한 국제사회의 노력과 기준, 그리 고 국제개발협력에 있어서 젠더를 기반으로 한 노력이 어떻게 인권증진에 기여할 수 있는가를 차례로 살펴보기로 한다. 또한 한국국제협력단(Korea International Cooperation Agency, 이하 $\mathrm{KOICA}$ )이 수행한 개발협력 프로그램에서 젠더 이슈가 어떻게 적용되었는지의 실태를 진단해보고 유의할 점과 앞으로의 과제 등을 논하기로 한다.

1) $\mathrm{UN}$ 이 성평등을 범분야 이슈로 규정한 것은 이미 2006년이다. UN 개혁을 위해 임명된 15 인의 각국 지도자들의 보고서. UN, Delivering as One: Report of the High-level Panel on United Nations System-wide Coherence in the area of development, humanitarian assistance and the environment, A/61/583, 20 Nov. 2006. https://documents-dds-ny.un.org/doc/UNDOC/GEN/N06/621/41/PDF/N0662141.pdf?OpenElement; 제33 차 인권이사회 결의 6/30, Human Rights Council Resolution 6/30, Integrating the human rights of women throughout the United Nations system, 33rd meeting, 14 Dec. 2007. http://ap.ohchr.org/documents/ E/HRC/resolutions/A_HRC_RES_6_30.pdf (접속일: 2017.11.22.) 


\section{II. 젠더와 개발}

\section{1. 젠더의 이해}

젠더(gender)라는 용어가 학술적 개념(Rubin, 1975)을 넘어서 보편화된 것은 1995년 베이징 세계여성회의 이후이다. 베이징 세계여성회의에서 채택된 정책문서인 베이징선언과 행동강령(UN, 1995)에 성평등(gender equality), 성인지(gender-sensitive), 성관점(gender perspectives) 등 젠더를 포함한 용어가 자주 등장하였다.2) 당시 한국 여성계에서는 젠더라는 용어를 어떻게 이해하고 어떻게 우리말로 번역해야 좋을지 고심하였다. 영어의 sex와 gender, sexuality가 우리말로는 모두 성으로 번역될 수밖에 없기 때문에 때로는 그낭 젠더 또는 섹슈얼리티라고 쓰기도 한다3).

sex가 성염색체에 의해 결정되는 생물학적 성을 지칭하는 데 반해, gender는 사회적으로 구축된 성의 개념이다. 즉 젠더란 남성과 여성에게 적용되는, 또는 남성과 여성 간의 규범, 역할, 관계 등의 특징을 말하는 개념이다. 사람은 생물학적으로 남성이나 여성으로 태어나지 만4), 가정에서, 사회에서 그리고 직장에서 동성 간에 또는 이성 간에 어떻게 관계를 맺어야 하는지에 대해 적절한 규범과 행동은 그가 속한 사회에서 배우게 되는 것이다. 생물학적인 남녀의 태생적 구분이 사회적으로 이미 형성되어 있는 여성다움, 남성다움의 기질을 갖추도록 만들어지고, 또한 남성은 가족부양자로, 여성은 가사담당자로 역할이 주어지는 것이 바로 젠더 인 것이다. 개인이 속한 사회에 이미 형성되어 있는 젠더 규범에 개인이나 집단이 맞지 않을 때 낙인이 찍히게 되고, 차별을 당하며 사회적으로 소외당하게 된다5).

2) 흥미롭게도 베이징 세계여성회의의 공식보고서 말미에 “"gender'라는 용어의 일반적 의미에 대한 대회장의 성명서"가 첨부되었다. 이 짧은 성명서는 여성지위위원회가 대회를 준비하는 과정에서 'gender'의 의미에 대한 질문이 제기되어 이를 해결할 담당 그룹이 구성되었고, 이를 면밀히 검토하였으나 기존에 사용되어 오던 의미와 다른 뜻으로 베이징 행동강령에 쓰인 것은 아니며 일반적으로 용인되는 의미로 사용되었다고 결론짓고 이를 베이징 대회에서 대회장이 직접 이를 공표하고 보고서에 수록하기로 결정하였다는 내용이다. United Nations, Report of the Fourth World Conference on Women, Beijing 4-15 Sept. 1995, A/CONF.177/20/Rev.1, 1996, p.218, Annex IV. Statement by the President of the Conference on the Commonly Understood Meaning of the Term "Gender".

3) 한국에서는 베이징선언과 행동강령의 gender-sensitive, gender-perspective, sexuality를 각각 성인지, 성관점, 성적본능으로 번역하였다. 한국여성개발원, 제4차 세계여성회의 북경선언·행동강령, 1995.

4) 남성과 여성 모두의 생식기관을 가지고 태어나는 간성인(intersex person)의 인권문제, 특히 의학적으로 불필요한 한쪽 생식기의 제거 수술로 인한 심각한 건강문제는 아주 최근에 들어서야 조금씩 실상이 알려지는 추세이다.

5) $\mathrm{WHO}$ 에 의하면 이러한 낙인, 차별, 소외가 모두 건강에 부정적 영향을 미치며, 남성이나 여성의 이분법적 카테고리에 맞지 않는 다른 정체성에 주의를 기울이는 것이 중요하다.

http://www.who.int/gender-equity-rights/understanding/gender-definition/en/ (접속일: 2017.11.22.) 
이와 같이 젠더란 사회적으로 구축된 성을 개념화한 것이므로 시대와 사회에 따라 젠더도 변화한다. 젠더에 기반한 개발협력사업을 통해 수원국에 존재하는 여성이 겪는 차별, 불평등한 사회적 관계를 시정하도록 할 수 있고, 또 이를 시정해야 하는 것이 SDG 목표5와 성 주류화의 요구이다.

제I장 속박을 받아 자신의 역량을 펼칠 기회를 갖지 못하는 것은 여성인권의 침해다. 젠더에 대한 고려는 정치, 경제, 사회, 문화의 모든 영역에서 여성이 인권을 보장받지 못하고 있는 현실을 타파해야할 필요에서다.

둘째는 성평등이 ‘똑똑한 경제’로 개발을 위한 훌륭한 수단이 되기 때문이다. 즉 성평등이 이루어지면 더 큰 경제적 효과를 가져와 사회발전에 큰 기여를 하기 때문인데 세계은행은 이를 세 가지로 설명하고 있다(World Bank, 2012: 3-6). 우선 여성이 교육이나 경제적 기회, 생산적 투여를 하는데 장애가 되는 요인을 제거하여 생산성 확대를 가져온다. 둘째, 여성의 지위를 개선하는 것은 다른 개발효과, 특히 자녀의 개발에 기여한다. 셋째는 여성이 적극적으로 사회적, 정치적으로 활발하게 결정에 참여하고 정책수립의 기회를 동등하게 갖게 되면 시간이 지나면서 기관이나 정책이 더욱 포용적으로 되어 더 나은 개발이 된다는 것이다,

\section{3. 젠더와 개발논의의 변천}

개발에 있어서 젠더의 중요성이 처음부터 인식된 것은 아니다. 경제발전에 있어서 젠더의 중요성을 처음 제기한 학자는 경제학자 보저럽(Ester Boserup)이다. 그는 여성의 경제활동 참여에 대륙 간에 차이가 있음에 주목하고 개발에 여성의 참여를 강조하였다(Boserup, 1970). 이와 같은 분석은 '개발에의 여성통합(Women in Development, 이하 WID)'으로 표현된다. 그의 연구는 젠더 문제의 중요성을 제기했다는 점에서 평가를 받았으나 비판도 제기되었다. 즉 경제발전의 이론적 틀이 신고전주의적 근대화 이론에 기초하고 있고, 여성의 종속적 지위에 대해 문제의식이 없으며, 남녀 간의 분업, 여성의 생산 활동에 대한 분석에 있어서 재생산의 중요지점인 가정과 그 구성원들의 관계가 경제개발에 있어서 여성의 역할을 결정한다는 점을 
간과했다는 비판을 받았다(Beneria and Sen, 1981).

이후 이를 보완하는 관점에서 등장한 접근방식이 '여성과 개발(Women and Development, 이하 $\mathrm{WAD})^{\prime}$ 이다. $\mathrm{WAD}$ 관점에서는 기존의 개발에 여성들이 통합되는 것이 아니라 여성들을 위한 독자적인 개발사업의 필요성을 주장한다. 남성들과 같이 개발에 참여할 경우 남성들의 헤게모니에서 벗어나기 힘들다는 인식에서이다(강선미, 2016: 408). 여성을 억압하는 가부장제 의 틀을 부정하고, 독자적 세력구축을 도모했던 1980년대의 급진적 여성운동과 맥을 같이 한다 고 볼 수 있다. 그러나 이 접근방법도 여성의 억압 상황을 포괄적, 통합적으로 보지 못한다는 비판에 직면하여 ‘젠더와 개발'이라는 새로운 접근방식에 의해 대체되게 된다.

'젠더와 개발(Gender and Development, 이하 GAD)'은 젠더라는 용어가 의미하는 바대로 개발의 모든 부문과 현실에 성 인지적 관점 즉 젠더적 관점을 적용하는 것이다. 개발정책과 프로그램을 통해 여성과 남성 간의 사회적 권력 관계, 성별 분업과 성 역할 등을 변화시켜 성평등을 성취하는 것을 지향한다. $\mathrm{WID}$ 에서 $\mathrm{WAD}$ 를 거쳐 지금의 $\mathrm{GAD}$ 적 접근법에 이르기까 지는 여성들의 조직적인 노력이 있었다. 


\section{III. 성평등의 국제적 기준 확립}

젠더에 기반한 개발협력, 즉 $\mathrm{GAD}$ 적 접근방식을 통해 여성인권을 강화하기 위해서는 그동안 성평등을 지향한 국제적 노력이 어떤 기준들을 정립했고, 그 내용이 무엇인가를 살펴보는 것이 필요하다.

\section{1. 베이징 행동강령(BPFA)}

$\mathrm{UN}$ 은 일찍이 1975 년을 ‘세계여성의 해’로 정하고, 멕시코시티에서 제 1 차 세계여성회의를 개최, 여성의 '평등, 발전, 평화(Equality, Development and Peace)'를 위한 여러 가지 사업과 활동을 펼치게 되었다. 이후 1976년 1985년을 '세계여성10년'으로 정하고, 5년 주기로 1980년 코펜하겐에서 제 2 차, 그리고 1985 년에 나이로비에서 제 3 차 세계여성회의를 개최하였다. 그 과정 에서 1976년에 UN여성기금(United Nations Development Fund for Women, UNIFEM)과 $\mathrm{UN}$ 국제연구연수원(International Research and Training Institute for the Advancement of Women, INSTRAW)이 설립되었다.

3 차 나이로비 대회 이후 10 년 만에 베이징에서 개최된 제 4 차 세계여성회의는 UN과 UN 회원국, 그리고 전 세계 여성계가 정열을 쏟아부은 대회였다. “여성의 눈으로 세계를 보라! (Look at the world through women's eyes!)”라는 슬로건 아래 189 개국 정부 대표가 참석 하였고, 3만여 비정부기구(Non Governmental Organization, 이하 NGO) 대표들이 NGO포 럼에 참석하여 각종 현안에 대한 최종 논의 끝에 베이징선언과 행동강령을 채택하였다6). 베이징 행동강령은 12 개 주요 관심분야별로 전략목표를 설정하고 각국 정부와 국제사회, 시민사회가 무엇을 해야 하는지를 조목조목 나열한 문서로서, 각국이 이행해야 할 정책문서로 채택되었다.

베이징 행동강령의 12 개 주요 관심분야는 여성과 빈곤, 여성의 교육과 훈련, 여성과 건강, 여성에 대한 폭력, 여성과 무력분쟁, 여성과 경제, 정치 권력과 정책 결정에 있어서의 여성, 여성의 발전을 위한 제도적 장치, 여성의 인권, 여성과 미디어, 여성과 환경, 여자어린이 등이다. 각 관심분야에서 여성의 평등, 발전, 평화를 이루기 위해서는 무엇을 해야 하는지가 자세히 수립되어 있다.

베이징 대회 이후 UN은 여성지위위원회를 통해 매년 베이징 행동강령의 이행 정도를 평가해

6) 베이징선언과 행동강령에 대한 자세한 사항은 다음에서 확인가능하다. http://www.un.org/womenwatch/daw/ beijing/pdf/BDPfA\%20E.pdf. (접속일: 2017.11.25.) 
오고 있다. 그리고 2010년에는 UN 내 여성정책기구인 UN 여성기구(UN WOMEN)가 기존의 여성관련 4개 기구를 통합하여 새롭게 출범하였다7). UN 여성기구는 여성지위위원회와 함께 성평등 관련 국제 규범을 정립하는 책임을 맡는 동시에, 전 세계 80여 개국에 설치되어 있는 국별, 지역별 사무소를 통하여 각국 차원에서의 성평등 실현을 지원하고 있다.

\section{2. 여성차별철폐협약(CEDAW)}

베이징 대회에서 대중화된 젠더라는 용어와 함께 여성차별철폐협약도 베이징회의 이후 널리 알려지게 되었다. 베이징 행동강령이 모든 나라가 이 협약을 비준하고 충실히 이행할 것을 문서 여러 곳에서 촉구했기 때문이다.

여성차별철폐협약(1979)은 여성의 차별을 금지하고 모든 여성의 평등권을 보장하는 포괄적 인 인권조약이다8). 이 협약은 모든 부문에 있어서의 여성에 대한 직접, 간접차별을 모두 금지한 다. 국가기관은 물론이고 개인, 기업, 조직에 의한 차별도 국가가 방지의무가 있다. 또한, 법제도 에 의한 차별뿐만 아니라 여성차별적인 전통과 관습의 폐지도 국가의 책임으로 규정하였다.

이 협약은 여성이 시민적·정치적 권리와 경제·사회·문화적 권리를 모두 동등하게 향유하고, 모성보호조치 등 생식(재생산) 건강권을 누리도록 보장하며, 여성차별적 관습과 문화를 시정하 도록 되어있다. 부문별로는 인신매매와 성매매착취, 시민적·정치적 권리, 국제대표성, 국적, 교 육, 고용, 건강, 대출 등 기타 경제적·사회적 분야, 농촌 여성, 법적 평등, 결혼과 가족관계에 있어서의 차별금지를 규정하고 있다.

이 협약을 비준한 국가는 여성차별철폐위원회에 4년마다 정기적으로 협약이행보고서를 제출 하고 심의를 받아야 한다. 심의 후 채택된 여성차별철폐위원회의 권고문에는 해당국 여성들에 대한 법적, 제도적, 실질적 차별의 상황을 종합적으로 담고 있다. 젠더기반 국제개발협력에 있어 수원국 여성들의 상황에 필요한 개발프로젝트를 기획, 집행할 때 여성차별철폐위원회의 권고문을 참고하는 것이 유용할 것이다.

7) 정식 명칭은 UN Women: United Nation's Entity for Gender Equality and Empowerment of Women이다. $\mathrm{UN}$ 내 여성국(Division for the Advancement of Women)과 UNIFEM, INSTRAW, 그리고 UN 사무총장 젠더문제 특별자문관실의 4개를 통합하였다. http://www.unwomen.org/en (접속일:2017.11.24.)

8) 2017. 12. 1. 현재 가입국은 189 개국이다. 협약에 대한 설명과 전문은 다음을 참조하기 바란다. http://www.ohchr.org/EN/ProfessionalInterest/Pages/CEDAW.aspx（접속일:2017.11.24.） 


\section{3. 사회권규약 상의 인권과 성평등}

여성협약이 제정되기 이전, 그리고 그 후에 추가로 제정된 핵심 국제인권조약이 분야별로 8개가 더 존재한다. 즉 자유권규약(1966), 사회권규약(1966), 인종차별철폐협약(1966)의 3개 핵심인권협약은 여성차별철폐협약이 제정되기 이전에 이미 존재하였다. 그리고 여성협약 제정 이후에는 부문별로 고문방지협약(1984), 아동권리협약(1989), 이주노동자권리협약(1990), 장 애인권리협약(2006), 강제실종보호협약(2006)의 5개 인권협약이 더 제정되었다. 이 협약들 모 두 여성의 평등권을 보장하고 있다. 특히 자유권규약과 사회권규약은 각각 시민적·정치적 권리 와 경제적·사회적·문화적 권리의 영역에서 모든 사람들이 차별을 받지 않을 것을 규정하고 있으며, 여성이 남성과 마찬가지로 동등한 권리를 향유할 것을 국가의 의무로 규정한 평등권조 항을 포함하고 있다.

핵심 인권조약들 중 사회권규약은 사회권 보장에 있어서 국제적 지원과 협력을 의무화하고 있다(제2조 1 항 $)^{9)}$. 빈곤 퇴치나 보건, 사회보장, 깨끗한 음용수의 확보, 기후변화로 인한 문제의 해결에는 모두 국제사회의 공동의 노력과 협력이 필요하다. 국가보고서 심의시 사회권위원회는 국제개발협력과 관련하여 정부가 특히 다음의 사항들을 유념하도록 요청한다.

첫째는 공적개발원조(Official Development Assistance, 이하 ODA)에 관한 것이다. 1970년 $\mathrm{UN}$ 결의에 의해 합의10)된 대로 국민총소득(Gross National Income, 이하 GNI)의 $0.7 \%$ 를 개발협력에 지원할 것을 사회권위원회는 모든 경제협력개발기구(Organization for Economic Cooperation and Development, OECD) 회원국에 권고하고 있다. 최근에 있었던 한국에 대한 심의에서도 사회권위원회는 $\mathrm{ODA}$ 가 $\mathrm{GNI}$ 의 $0.7 \%$ 에 도달하도록 점차 늘려나갈 것과 유. 무상 원조 간의 균형을 맞출 것을 권고하였다11). 동시에 $\mathrm{ODA}$ 관련 사업에 인권 기준을 적용하 는지의 여부에 관심을 갖고, 인권에 기반한 개발협력, 보다 구체적으로는 인권영향평가를 개발 협력정책에 통합시킬 것을 권고한다12).

9) 사회권규약 제 2 조 1 항, "이 규약의 각 당사국은 특히 입법 조치의 채택을 포함한 모든 적절한 수단에 의하여 이 규약에서 인정된 권리의 완전한 실현을 점진적으로 달성하기 위하여, 개별적으로 또한 특히 경제적, 기술적인 국제지원 과 국제협력을 통하여, 자국의 가용 자원이 허용하는 최대한도까지 조치를 취할 것을 약속한다."

10) OECD DAC, "History of the $0.7 \%$ ODA Target". https://www.oecd.org/dac/stats/ODA-history-of-the-0-7-target.pdf (접속일:2017.11.24.)

11) 사회권위원회, 대한민국 제 4 차 보고서에 관한 최종견해, $\mathrm{E} / \mathrm{C} .12 / \mathrm{KOR} / \mathrm{CO} / 4,2017.10 .19$, 문단 20 21. file:///C:/Users/ MASTER/Downloads/G1732316.pdf (접속일:2017.11.24.)

12) 한 예로 사회권위원회, 네덜란드 제6차 보고서에 관한 최종견해, $\mathrm{E} / \mathrm{C} .12 / \mathrm{NLD} / \mathrm{CO} / 6,2017.7 .6 .$, 문단 9 10. file:///C:/ Users/MASTER/Downloads/G1718296.pdf（접속일:2017.11.24.） 
둘째는 민간차원의 국제협력, 주로 기업을 통해서 이루어지는 투자나 개발 활동에 관한 것이 다. 광산이나 유전개발 등의 기업 활동으로 인해 원주민 등 주민들이 강제퇴거를 당하고, 공동경 작지나 호수 등의 이용금지조치, 또는 환경오염 등의 사례가 끊임없이 발생하고 있다. 사회권위 원회는 개발의 과정에서 이러한 인권침해가 일어나지 않도록 하고, 지역주민들과 사전에 충분히 협의를 거치도록, 또 적정한 보상이 이루어지도록 정부가 제도를 마련하라는 권고를 되풀이하고 있다.

사회권위원회가 최근 채택한 일반논평 제 24호13)는 기업 활동에 관한 우려를 담고 있다. 일반논평 24호는 '기업 활동에 있어서 경제적, 사회적, 문화적 권리에 관한 국제규약에 따른 국가 의무'에 대한 것으로, 여성, 아동, 원주민, 소수인종 등 사회적 약자들이 기업 활동으로 인한 부정적 영향을 더 받으며 복합적 차별을 받을 가능성도 기술하였다. 위원회는 '원주민 여성과 소녀들을 포함해서, 여성과 소녀들에 대한 기업 활동의 특정한 영향을 해소하고, 경제, 사회, 문화적 권리에 부정적 영향을 줄 수 있는 기업 활동을 규제하기 위한 모든 조치에 성(性) 인지적 관점을 통합할 것'과 '기업의 상위층을 포함, 노동시장에서의 여성 대표성 제고를 위해 한시적 특별조치를 포함한 적절한 조치'를 주문하였다.

\section{4. 기타 주요 UN회의 합의문서들}

세계여성회의 이외에도 성평등의 국제기준의 정립에 중요한 영향을 끼친 몇몇 UN회의와 그 회의에서 채택된 문서가 있다. 1993년의 비엔나 세계인권회의는 모든 인권의 보편성, 불가분 성, 상호의존성을 확인한 회의이다. 여성이 처한 다양한 차별과 폭력의 현실을 우려하면서 “여성 과 소녀의 인권은 보편적 인권의 한 부분으로 양도불가능하고, 필수적이며, 불가분하다14).”라고 천명하였다. 또한, 정치적, 시민적, 경제적, 사회적, 문화적 모든 부문에서의 완전한 참여, 그리고 성별에 기인한 모든 형태의 차별을 폐지할 것을 촉구하였고, 또한 젠더기반 폭력과 모든 형태의 성적 괴롭힘과 착취는 인간의 존엄성과 가치와 양립할 수 없으며 철폐되어야 한다고 선언하였 다. 또한 경제사회개발, 교육, 안전한 모성과 건강 보호, 사회보장 등의 분야에서 법적인 조치와

13) 사회권위원회, 일반논평 제 24 호: 기업활동과 관련하여 경제적, 사회적, 문화적 권리에 관한 국제규약에 따른 국가의무, 국가인권위원회 번역, 문단 8 9. 원문은 Committee on Economic, Social and Cultural Rights, General comment No. 24(2017) on State obligations under the International Covenant on Economic, Social and Cultural Rights in the context of business activities. file://C:/Users/MASTER/Downloads/G1723717\% 20(4).pdf (접속일: 2017.11.24.)

14) Vienna Declaration and Programme of Action, 문단 18.에 대한 자세한 사항은 다음을 참조하기 바란다. http://www.ohchr.org/EN/ProfessionalInterest/Pages/Vienna.aspx（접속일: 2017.11.24.) 
국가 행동, 국제협력으로 이러한 과제를 성취할 수 있다고 하였다15). 이 비엔나회의에서 '여성의 권리는 인권(Women's rights are human rights)'이라는 구호가 등장하였고, 이는 2년 후 베이징회의에서 확산, 보편화되었다.

연이어 개최된 1994 년의 카이로 국제인구개발회의에서는 보건과 생식건강 분야의 국제적 기준이 결정되었다. 이 회의에서 채택한 행동프로그램은 서두에 총 15 가지의 인권원칙을 천명 하고 그 원칙 중의 하나로 성평등을 포함하였다. 즉 “성평등과 성 형평성, 여성 역량강화의 진전, 모든 종류의 여성폭력철폐, 그리고 여성들 자신에 의한 출산력 통제는 인구와 개발관련 프로그램의 초석"이라고 하면서, 이어서 비엔나 행동프로그램의 여성인권 부분을 그대로 인용 하였다(UN, 1994).

이 회의에서는 가족계획이나 출산력 조절에 있어 법의 허용범위 내에서 안전하고 효과적인 저렴한 방법에 대한 정보를 받고 개인이 선택할 권리, 그리고 부부와 개인들이 자유롭고 책임성 있게 자녀의 수와 터울, 시기를 결정할 수 있는 권리, 그리고 차별과 강압, 폭력 없이 재생산결정 을 할 수 있는 권리를 가질 수 있어야 한다고 규정하였다(UN, 1994: 문단 7.2, 7.3). 즉 개발에 있어 생식건강에의 권리가 어떻게 관련되는가를 인권의 측면에서 천명하였다.

1990년대에는 이외에도 리우환경회의, 스톡홀름 사회개발정상회의, 더반 인종차별철폐회의 등 연이은 세계회의의 연속이었다. 이런 모든 국제회의에 여성운동단체의 대표들이 참석하여 성평등의 문제를 제기하고 채택되는 문건이 성평등 이슈를 올바로 포함하도록 적극적으로 활동 하였다.

\section{5. 안보리 결의 1325 호}

1990년대의 이러한 노력이 쌓여 2000년 들어 또 하나의 중요한 시금석이 만들어졌다. UN 안전보장이사회(이하 안보리)가 처음으로 여성관련 결의안을 채택한 것이다. 여성, 평화, 안보 에 관한 안보리 결의 1325 호는 전시에 여성인권 침해가 빈번한 것에 주목하고, 분쟁의 예방, 관리, 해결을 위한 기구와 모든 정책 결정에 여성의 대표성 증가, 평화유지군 활동에 젠더관점 통합, 모든 평화조약 체결과 이행에 젠더관점을 채택하고 특히 송환과 정착과정 및 재활, 사회통 합, 분쟁 후 재건에 여성과 소녀의 특별한 욕구에 부응할 것, 무력갈등 상황에서 갈등의 모든 당사자들이 여성과 소녀들을 젠더기반 폭력, 특히 강간과 기타 성적 학대, 그리고 모든 폭력으로

15) Vienna Declaration and Programme of Action, 문단 18.에 대한 자세한 사항은 다음을 참조하기 바란다. http://www.ohchr.org/EN/ProfessionalInterest/Pages/Vienna.aspx（접속일: 2017.11.24.) 
부터 보호하기 위한 특별조치를 취할 것을 촉구하는 등 18 개의 결의내용을 담고 있다(UN, 2000).

안보리 결의 1325 호 이후 안보리는 지금까지 계속 7 개의 후속 결의안을 추가로 채택하면서 결의 1325호를 강화하고 그 실질적 이행을 여러 부문에서 촉구하였다16). 이에 따라 각국에서는 결의 1325 호 이행을 위한 국가행동계획을 수립하여 여성의 참여를 증진시키는 등 젠더관점을 통합한 정책을 수립하였다. 우리나라도 2014년 안보리 결의 1325호 이행을 위한 국가행동계획 을 수립하였으며, 정부 7 개 부처와 함께 KOICA가 참여하였다. 이제 3 년이 지나 제 2 기 행동계 획을 새로이 수립하는 과정에 있으며, 경찰청이 새롭게 합류하기로 하였다17).

분쟁 중이거나 분쟁을 겪은 국가나 지역에 대한 개발협력 프로그램을 시행할 경우 안보리 결의 1325 호의 내용을 통합하여 여성의 참여를 보장하고 피해 여성에 대한 구호, 예방계획 등을 포괄하는 것이 필요하다. 아울러 여성차별철폐위원회의 분쟁지역 여성에 관한 일반논평 30호18)의 내용도 같이 참고하는 것이 필요하다.

16) 이 추가 안보리 결의안들은 결의 1820호(2008), 1888호(2009), 1889호(2009), 1960호(2010), 2106호(2013), 2122호 (2013), 2242호(2015) 등이다. 자세한 사항은 다음을 참조하기 바란다. http://www.unwomen.org/en/whatwe-do/peace-and-security/global-norms-and-standards (접속일: 2017.11.24.)

17) 지금까지 63개국에서 안보리 결의안 1325 이행을 위한 국가행동계획을 수립하였다. 우리나라의 국가행동계획 이행을 지난 3년간 합동으로 수행해 온 7 개 부처는 외교부, 여성가족부, 국방부, 통일부, 행정안전부, 법무부, 교육부이다. 여성가족부, UN안보리결의 1325호 제2기 국가행동계획 공청회 자료집, 2017. 11. 22.

18) Committee on the Elimination of Discrimination against Women, General Recommendation 30 on women in conflict prevention, conflict and post-conflict situations, CEDAW/C/GC/30. file:///C:/Users/MASTER/ Downloads/N1354331.pdf (접속일: 2017.11.24.) 


\section{IV. 성평등 달성을 위한 전략: 성 주류화}

성평등의 내용을 실질적으로 달성하기 위해 채택된 전략은 성 주류화이다. 성 주류화의 개념

을 정확하게 이해해야 국제개발협력에 있어서 젠더를 기반으로 한다는 것의 의미를 쉽게 인식할 수 있다19).

\section{1. 성 주류화란?}

성 주류화는 1995년의 베이징 행동강령에서 성평등을 달성하기 위한 전략으로 채택되었다. $\mathrm{UN}$ 경제사회이사회가 합의한 결론(1997/2)에서 정의내린 성 주류화는 “모든 분야, 모든 차원 에서, 법률안이나 정책, 프로그램 등 계획된 행동이 여성과 남성에게 함의하는 바를 추산하는 과정이다. 이는 정치, 경제, 사회 모든 부문에서 정책과 프로그램을 입안, 시행, 모니터링, 평가하 는데 여성과 남성의 관심과 경험을 필수적인 차원으로 하여 여성과 남성이 동등하게 혜택을 받고 불평등이 지속되지 않도록 하기 위한 전략이다. 궁극적 목표는 성평등을 달성하는 것이다."

\section{2. 성 주류화의 분석 틀}

성 주류화에 필요한 분석 틀로 제시된 내용은 다음과 같다.

- 여성과 남성에게 책임, 활동, 관심, 우선순위가 무엇인지 질문하여 그들의 경험이나 문제가 어떻게 다른지 파악한다.

- '가족', ‘세대', ‘사람 등으로 표현되는 질문이나 정책 속에 숨겨져 있는 내용을 보다 정확하게 드러낸다.

- 여성과 남성의 경험과 상황 분석에 필요한 성별 통계나 정보를 입수한다.

- 생활방식에 영향을 줄 수 있는 사안의 결정에 있어 남성뿐만 아니라 여성의 의견과 참여를 구한다.

- 여성들의 참여가 많은 활동(가사일 포함)에 관심을 기울인다.

- 모든 여성과 모든 남성이 동일한 옥구와 관점을 가지고 있다는 가정을 하지 않는다.

- 문제나 이슈, 제안된 정책대안을 젠더의 관점에서 분석하고 혜택이나 기회를 형평성 있게 배분할 수 있는 방향의 방안을 찾는다.

19) 이 부분은 다음을 주로 참고하였다. United Nations, Gender Mainstreaming: An Overview, New York, 2002. 


\section{3. 성 주류화에서 고려해야 할 기본 문제들}

국가마다 또 분야마다 상황은 다르지만 공통의 젠더 이슈는 대체적으로 다음과 같다.

- 정책 결정에의 참여, 대표성 등 정치적 권력에 있어서의 불평등

- 가정 내 불평등

- 법적 지위와 자격에 있어서의 차이

- 경제 부문의 성별 분업

- 가사/무보수 노동 부문의 불평등

- 여성에 대한 폭력 (또는 젠더기반 폭력)

- 성차별적인 사고, 관습, 태도 


\section{V. 젠더기반 국제개발협력을 통한 여성인권 강화}

\section{MDGs에서 SDGs로의 이행}

제I장

개

발

협

력

이

슈

제II장

제피장

문제점이 지적되었다. 성평등관련 목표는 성취가 너무 느리게 진행되었고, 인권적 관점이 결여 되었으며 특히 모든 목표에 젠더관점의 통합이 전혀 이루어지지 않았다20).

Post-2015를 논의하는 과정에서 전 세계 500여 개 여성운동 단체들은 여성주요그룹 (Women's Major Group)을 구성하여 UN의 공식 파트너로서 MDGs의 미비점을 보완하기 위한 적극적 참여와 로비활동을 펼쳤다21). 여성계의 요구는 크게 4 가지로 축약된다. 즉 (1)성 평등을 독자 목표로 설정해 줄 것과 모든 목표에 성 주류화를 통합시켜 줄 것, (2) 성과 생식건 강 및 권리, (3)여성, 평화, 안보 문제, (4)여성의 현실을 고려한 경제구조의 진정한 변혁 등이었 다22).

20) Commission on the Status of Women, Challenges and achievements in the implementation of the Millennium Development Goals for women and girls: Moderator's summary, E/CN.6/2014/INF/6, 동일한 패널에 대한 $\mathrm{NGO}$ 의 요약은 좀 더 비판적이다. 즉 $\mathrm{MDG}$ 목표 1 의 경우 남성보다 여성이 더 빈곤하고 극빈자의 경우에도 여성이 더 심각하며, 여성은 토지나 생계수단이 더 없고, 무보수 돌봄 노동도 여성이 훨씬 더 많이 담당하고 있으나 목표 1 의 경우 이런 젠더 분석이 전혀 없다. 자세한 사항은 다음에서 확인가능하다. http://www.graduatewomen.org/ challenges-achievements-implementation-millennium-development-goals-women-girls-gaps-lessonslearned- ${ }^{-}{ }^{-}{ }^{-}$-58 (접속일: 2017.11.24.)

21) Women's Major Group은 리우환경회의에서 창립되어 1996년부터 적극적 활동을 펼쳐왔다. 사무국은 WEDO (Women's Economic and Development Organization)과 IWHC(International Women's Health Coalition) 이 맡고 있다. SDGs 논의의 전 과정에 적극적으로 참여하였다. 자세한 사항은 다음에서 확인가능하다. http://www.women majorgroup.org (접속일: 2017.11.24.)

22) Women's Major Group이 반기문 UN 사무총장의 보고서, “A Life of Dignity for All: accelerating progress towards the Millennium Development Goals and advancing the United Nations development agenda beyond 2015”에 대한 의견서로 사무총장에게 보낸 2013.9.6.일자 서한. Women's Major Group Response to UN Secretary-General's Report on MDGs and Post-2015 Framework. https://iwhc.org/resources/ womens-major-group-response-un-secretary-generals-report-mdgs-post-2015-framework (접속일: 2017.11.24.) 


\section{SDGs와 SDG5 (성평등) 세부목표}

여성계의 요구대로 지속가능개발목표 중 독자 목표로 '성평등 달성 및 여성·여아의 역량강화' 가 포함되었다. 그리고 목표 5 의 세부목표로 아래 <표 $1>$ 에 있는 대로 9 가지가 설정되었다.

〈표 1〉 SDG 5: 성평등 달성 및 모든 여성과 여아의 역량강화

\begin{tabular}{|l|l|}
\hline \multicolumn{2}{|c|}{ 세부 목표(targets) } \\
\hline 5.1 & 세계 모든 여성과 여아에 대한 모든 형태의 차별 철폐 \\
\hline 5.2 & $\begin{array}{l}\text { 공적 및 사적 영역에서 모든 여성과 여아에 대한 인신매매, 성 착취 및 기타 형태의 착취를 } \\
\text { 포함한 모든 형태의 폭력 철폐 }\end{array}$ \\
\hline 5.3 & 아동 결혼, 조혼, 강제결혼 및 여성 성기 절단 등 모든 악습 철폐 \\
\hline 5.4 & $\begin{array}{l}\text { 각국에 맞는 공공서비스, 인프라, 사회보장정책의 제공을 통한, 그리고 가구와 가족내 책임의 } \\
\text { 공유를 통한, 무급 돌봄 노동 및 가사노동 가치 인정 }\end{array}$ \\
\hline 5.5 & $\begin{array}{l}\text { 정치, 경제, 공공생활의 모든 수준의 의사결정에 여성의 완전하고 효과적인 참여 및 동등한 } \\
\text { 리더십 기회 보장 }\end{array}$ \\
\hline 5.6 & $\begin{array}{l}\text { 국제인구개발회의의 행동프로그램과 베이징 행동강령 및 그 후속 회의의 결과문서에 따라 성 } \\
\text { 및 생식건강과 생식 권리에 대한 모든 사람의 동등한 접근 보장 }\end{array}$ \\
\hline $5 . a$ & $\begin{array}{l}\text { 여성에게 국내법에 따라 경제적 자원에 대한 동등한 권리를 줄 뿐만 아니라 토지, 자산, 재정서 } \\
\text { 비스, 상속, 자연 자원의 소유와 관리에 대한 접근에 있어서도 동등한 권리를 주기 위한 개혁 } \\
\text { 수행 }\end{array}$ \\
\hline $5 . b$ & 여성역량강화를 위해, 특히 정보통신기술을 포함한 기술사용의 확대 \\
\hline $5 . c$ & $\begin{array}{l}\text { 모든 수준에서 성평등 증진과 여성 - 여아의 역량강화를 위한 건전한 정책과 강제력 있는 법안의 } \\
\text { 채택과 강화 }\end{array}$ \\
\hline
\end{tabular}

출처: UN (2015)

이에 앞서 지속가능개발을 위한 선언문의 앞부분에서는 의제의 중요한 한 부분으로 성평등과 성 주류화를 천명하였다. '여성과 여아에 대한 모든 형태의 차별과 폭력은 제거될 것'이며, 성평 등을 이행함에 있어 '체계적인 성 관점의 주류화가 지극히 중요'하다고 선언하였다(UN, 2015: 문단 20).

이 선언대로라면 SDGs 1 17의 모든 목표에 SDG5가 통합된 성 주류화가 필요하다. 그러나 성 주류화가 가시적으로 표현된 것은 <표 $2>$ 에서 보는 대로 16 개 목표 중에서 10 개에 해당하는 목표들에 한정되었다. 여성, 여아, 성 격차, 모성사망률, 임산부, 수유기 여성, 생식건강, 청소년, 성평등, 성 인지적 등의 용어가 세부목표에 언급된 경우 젠더 이슈가 포함된 것으로 아래에 열거하였다. 어느 목표에는 보다 전면적으로, 또는 어느 목표에는 아주 일부분에만 명시되었다. 
〈표 2〉세부목표에 젠더관점이 포함된 SDGs 분야

\begin{tabular}{|c|c|}
\hline $\begin{array}{l}\text { SDG } 1 . \\
\text { 빈곤 퇴치 }\end{array}$ & $\begin{array}{l}1.2 \text { 2030년까지 국가별 정의에 따른 모든 범주에서 모든 연령대의 빈곤한 남성, } \\
\text { 여성, 아동의 비율을 최소한 절반으로 감소 } \\
1.4 \text { 2030년까지 모든 남성과 여성, 특히 빈민층 및 취약계층의 경제자원에 대한 } \\
\text { 동등한 권리와, 기초 서비스, 토지 및 다양한 형태의 자산 소유 및 관리, 상속, } \\
\text { 자연 자원, 적절한 신기술, 소액융자 등 금융서비스에 대한 접근 보장 }\end{array}$ \\
\hline $\begin{array}{l}\text { SDG } 2 . \\
\text { 기아 해소 }\end{array}$ & $\begin{array}{l}2.2 \text { 2030년까지 모든 영양결핍 해소, 청소녀, 임부, 수유기 여성 및 노인의 영양적 } \\
\text { 필요에 대처 } \\
2.3 \text { 2030년까지 소규모 식량 생산자의 생산성과 수입을 두 배 증가, 특히 여성, } \\
\text { 원주민, 가족농, 유목민, 어부 등 포함해서, 토지와 기타 생산자원, 투자, 지식, } \\
\text { 재정서비스, 시장, 부가가치/비농업 고용기회 제공을 통함 }\end{array}$ \\
\hline $\begin{array}{l}\text { SDG } 3 . \\
\text { 건강과 복지 }\end{array}$ & $\begin{array}{l}3.1 \text { 2030년까지 전 세계 모성사망률을 출산 } 10 \text { 만 명당 } 70 \text { 명 미만으로 감소 } \\
3.7 \text { 2030년까지 성 및 생식건강 서비스 누구나 이용 가능케 하고, 가족계획, 정보와 } \\
\text { 교육, 국가전략과 프로그램에 생식건강 통합 ※ }\end{array}$ \\
\hline $\begin{array}{c}\text { SDG } 4 . \\
\text { 양질의 교육 }\end{array}$ & $\begin{array}{l}4.1 \text { 2030년까지 모든 소년·소녀들이 무상으로 평등하게 양질의 초등, 중등교육을 } \\
\text { 완료하고 효과적인 배움의 결과 획득 } \\
4.2 \text { 2030년까지 모든 남녀 아동들이 양질의 조기 아동발달, 돌봄, 취학 전 교육을 } \\
\text { 받아서 초등교육 진학 준비를 할 수 있도록 지원 } \\
4.3 \text { 2030년까지 모든 여성과 남성에게 경제적 부담 없는 양질의 기술교육, 직업교 } \\
\text { 육, 대학을 포함한 고등교육에의 동등한 접근성 확보 } \\
4.5 \text { 2030년까지 교육에서의 성 격차를 철폐하고 모든 교육과 직업훈련에 대한 장애 } \\
\text { 인, 원주민, 아동 등 취약계층의 동등한 접근성 확보 } \\
4.6 \text { 2030년까지 모든 청년 및 상당한 비율의 성인 남녀의 문해력/수학력 확보 } \\
\text { 4.7 2030년까지 모든 학습자들이 지속가능발전 증진에 필요한 지식과 기술을 습득 } \\
\text { 할 수 있도록 지속가능발전과 지속가능한 생활 스타일, 인권, 성평등, 평화와 } \\
\text { 비폭력 증진, 지구시민권, 문화다양성의 존중 및 문화가 지속가능발전에 기여하 } \\
\text { 는바 등 교육 } \\
4 . a \text { 교육시설을 아동, 장애, 성 인지적으로 건설하고 개선하며, 안전하고 비폭력적이 } \\
\text { 며 통합적이고 효율적인 교육환경을 모두에게 제공 }\end{array}$ \\
\hline $\begin{array}{r}\mathrm{SDG} \\
\text { 깨끗한 둗 }\end{array}$ & $\begin{array}{l}6.2 \text { 2030년까지 적절하고 공평한 위생시설에 대한 모두의 접근성 확보, 공개장소에 } \\
\text { 서의 배변 척결, 여성과 여아 및 취약한 상황의 사람들에게 특히 관심 필요 }\end{array}$ \\
\hline $\begin{array}{l}\text { SDG } 8 . \\
\text { 좋은 일자리와 } \\
\text { 경제성장 }\end{array}$ & $\begin{array}{l}8.5 \text { 2030년까지 모든 여성과 남성-청년, 장애인 포함-에게 완전하고 생산적인 고 } \\
\text { 용과 좋은 일자리를 확보하고 동일가치 노동에 동일 임금 보장 } \\
8.8 \text { 이주노동자, 특히 여성 이주노동자를 포함한 모든 노동자들과 불안정 고용상태 } \\
\text { 의 노동자들의 노동권 보호 및 안전한 노동 환경 보장 }\end{array}$ \\
\hline $\begin{array}{l}\text { SDG } 10 . \\
\text { 불평등 감소 }\end{array}$ & $\begin{array}{l}10.2 \text { 2030년까지 연령, 성별, 장애, 인종, 민족, 출신, 종교, 경제적 또는 기타 지위와 } \\
\text { 관계없이 모든 사람들의 역량강화와 사회적, 경제적, 정치적 통합 증진 }\end{array}$ \\
\hline $\begin{array}{l}\mathrm{SDG} 11 . \\
\text { 지속가능한 } \\
\text { 도시와 공동체 }\end{array}$ & $\begin{array}{l}11.2 \text { 2030년까지 안전하고 지불가능하며 접근성 높고 지속가능한 대중교통 시스템 } \\
\text { 을 모두에게 제공, 이는 무엇보다 여성, 어린이, 장애인, 노인 등 취약계층의 } \\
\text { 특별한 요구 조건에 부합하는 대중교통을 확대함으로써 도로안전 개선 } \\
11.7 \text { 2030년까지 모두에게 안전하고 통합적이며 접근성 좋은 공공녹지 공간을 제 } \\
\text { 공, 특히 여성과 어린이, 노인과 장애인 고려할 것. }\end{array}$ \\
\hline & \\
\hline
\end{tabular}




\begin{tabular}{c|c}
\hline 기후행동 & $\begin{array}{l}\text { 록 역량강화 메커니즘 설립, 여성, 청년, 지방 및 소외된 지역에 특별한 관심 } \\
\text { 포함 }\end{array}$ \\
\hline $\begin{array}{c}\text { SDG 17. } \\
\text { 글로벌 } \\
\text { 파트너십 }\end{array}$ & $\begin{array}{r}17.18 \text { 2020년까지 저개발국과 소도서 개도국을 포함한 개발도상국들이 소득수준, } \\
\text { 성별, 연령, 인종, 민족, 이주 신분, 지역, 또는 기타 국가적 특성별로 양질의 } \\
\text { 시의적 절하고 신뢰할만한 데이터 확보를 획기적으로 늘리기 위해 역량강화 } \\
\text { 지원을 증진 }\end{array}$ \\
\hline
\end{tabular}

※ 여기에는 젠더가 언급되지 않았으나 생식건강이 월경, 임신, 출산 등 여성의 모성과 보다 더 밀접하게 연결되어 있어 포함시킴.

출처: UN (2015)

세부목표에 젠더관련 사항이 전혀 언급되지 않은 6 개 목표는 다음과 같다.

- SDG 7: 부담 가능한 깨끗한 에너지

- SDG 9: 산업, 혁신 및 인프라

- $\mathrm{SDG} 12$ : 책임 있는 소비와 생산

- SDG 14: 해저 생명

- SDG 15: 육상 생명

- $\mathrm{SDG} 16$ : 평화, 정의 및 강한 기구

그러나 이 목표에도 각각 많은 젠더 이슈들이 관련되어 있다. 예를 들어 SDG 7의 경우 '7.1 부담 가능하고 믿을 만한 근대적 에너지 서비스를 누구나 이용'할 수 있게 하는 것인데, 많은 개발도상국의 여성들이 매끼 식사준비에 나무를 사용해 불을 피워야 하는 실정에서 태양열 을 이용한 조리를 할 수 있도록 하는 것은 소자본과 기술로 가능한 일이다. 또 SDG 16 에서 ' 16.1 전 세계의 모든 형태의 폭력과 그로 인한 사망의 현저한 감소'와 관련해서는 가정폭력, 강간 등 여성에 대한 일상적인 폭력이 포함된다. 이뿐만 아니라 무력갈등 시 행해지는 여성에 대한 전쟁범죄, 반인도적 범죄에 대한 대책과 이의 처벌, 배상을 위한 재판소 등의 젠더 이슈가 내포되어 있다. 따라서 모든 목표에 대해 그 세부목표에 명시적으로 젠더 이슈나 관점이 포함되 지 않았더라도 성 주류화를 위한 내용을 새롭게 보강하는 것이 좋을 것이다.

$\mathrm{SDG}$ 5는 여성계가 지속적으로 요구한 대로 독자 목표로 설정되었고, 그 세부목표에도 여성 들의 요구가 상당 부분 반영되었다. 또한 다른 목표들에도 젠더 이슈들이 부분적으로 포함되었 다. 앞으로 2030년까지 이를 성공적으로 달성하기 위해서는 SDG 5의 세부목표와 더불어 다른 목표에도 보다 더 폭넓게 성 주류화를 도입하고 그 이행을 모니터, 평가할 수 있는 효과적 지표를 확정하는 것이 필요하다. 


\section{3. 젠더기반 개발협력의 실제: KOICA 사업을 중심으로}

성평등과 여성역량강화 자체를 목적으로 설정하는 사업들은 그 주된 목적과 대상이 뚜렷하기 때문에 사업의 구상이나 계획, 이행, 평가가 비교적 쉽다. 그러나 SDG의 다른 분야 사업일 경우 젠더에 대한 이해도 부족하고 성평등의 내용을 잘 모르므로 어떻게 젠더 이슈를 도입해야 할지 난감한 상황에 처하게 된다. 게다가 명시적으로 범분야 이슈로 젠더를 고려할 것이 필수 요구사항에 포함되지 않으면 성 주류화 자체를 간과하게 된다.

이런 점을 염두에 두고 $\mathrm{KOICA}$ 의 완료 사업을 예로 들어 젠더기반 개별협력이 어떻게 진행 되었는지를 살펴보고, 어떤 점이 개선되어야 하는지 점검해 보기로 한다. 자료로는 KOICA가 비교적 최근에 사업을 종료하고 2016년 평가를 마친 개발협력사업을 택하였다. <표 3>에 표시된 것과 같이 아시아, 아프리카, 남미 등 여러 나라에서 12 개 개발협력사업이 진행되어 그 평가가 이루어졌다23).

$\mathrm{KOICA}$ 는 개발협력사업의 평가에 있어 $\mathrm{OECD}$ 개발원조위원회(Development Assistance Committee, DAC)의 5대 평가 기준에 따라 적절성, 효과성, 효율성, 지속가능성, 영향력을 주요 평가 기준으로 사용하고 있다. 그리고 이 기본적인 5 대 기준에 더하여 젠더(성 주류화) 및 환경에 대한 고려를 범분야 이슈로 포함시켜, $\mathrm{KOICA}$ 사업이 성평등 및 환경문제를 고려하 여 수행되었는지를 평가하고 있다(KOICA, 2016:12). 그러나 성평등이나 환경보전에의 기여는 실제 평가의 점수에 독자적 항목으로 반영되지는 않고 있다24).

<표 3>에서 보는 바와 같이 12 개 $\mathrm{KOICA}$ 개발협력사업 중에서 젠더가 고려되어 계획된 것은 4 개 사업( $1,5,6,10$ 번 사업들)에 불과하여 전체 사업 수의 $2 / 3$ 는 성평등이라는 범분야 이슈를 전혀 고려하지 않았다. 또한, 사업평가에 젠더 고려 여부를 평가의 항목으로 전혀 포함하 지 않은 경우도 4 개 경우나 되었다 $4,9,11,12$ 번 사업들). 이 경우 평가단 자체도 성 주류화의 필요성을 인지하지 못하고 있다는 방증이다. 파라과이 아순시온 첨단교통관리체계사업의 경우,

23) 표에 열거된 KOICA 개발협력사업은 홈페이지상의 2016년도 사업평가보고서(프로젝트 종료, 또는 평가보고서)에는 11 건으로, 2016 평가연보에는 12 건으로 게재되어 있다. 이는 스리랑카의 동부와 북부에서 진행된 2 개의 사업을 홈페이지에는 하나의 보고서로 통합하여 작성, 게재한 반면, 평가연보에는 2 개의 사업으로 게재하였기 때문이다. 여기서는 2 개 사업으로 취급하였다. 홈페이지에 게재된 평가보고서는 국문과 영문 2 가지로 되어있으며 완결판이고, 평가연보에 게재된 것은 그 축약본이다. KOICA 2016 평가연보 http://www.koica.go.kr/download/2016/2016_ annual_kr.pdf (접속일: 2017.11.24.)

24) 평가등급은 국무조정실의 $\mathrm{ODA}$ 사업평가등급제 시행지침(2015.6)에 따른 등급부여로, 적절성, 효율성, 효과성/영향 력, 지속가능성의 각 부문에서 1점 4 점으로 평가해서 4 개 항목의 점수를 합산한다. 종합점수가 14 점 이상이면 매우 성공적, 11 점 이상 14 점 미만이면 성공적, 8 점 이상 11 점 미만이면 부분 성공적, 8점 미만이면 미흡으로 평가함, 범분야 부문은 따로 평가되지 않는다. 
평가단은 이 사업에는'젠더 이슈에 대한 고려는 해당되지 않는다’라고 기술하였다25).

〈표 3〉 KOICA 프로젝트 젠더 이슈 고려 및 평가항목 포함 여부

\begin{tabular}{|c|c|c|c|c|}
\hline 국가/지역 & 사업명 & 사업 기간 & $\begin{array}{l}\text { 사업비 } \\
\text { (US\$) }\end{array}$ & $\begin{array}{l}\text { 젠더고려여부 } \\
\text { (평가포함여부) }\end{array}$ \\
\hline $\begin{array}{l}\text { 1. 방글라데시 } \\
\text { 치타공 }\end{array}$ & 직업훈련원 역량강화사업 & $2011-2013$ & 480만 & $\circ \quad(0)$ \\
\hline $\begin{array}{l}\text { 2. 베트남 } \\
\text { 부온호현 }\end{array}$ & 상수도시설 건설사업 & 2010-2013 & 450만 & $x(0)$ \\
\hline $\begin{array}{l}\text { 3. 라오스 } \\
\text { 비엔티안주 문군 }\end{array}$ & $\begin{array}{l}\text { 관개용 댐 및 수로건설 } \\
\text { 사업 }\end{array}$ & 2008-2011 & 320만 & $x(0)$ \\
\hline 4. 라오스 & $\begin{array}{l}\text { 지도제작 인력양성 및 } \\
\text { 지형도 제작사업 }\end{array}$ & $2014-2017$ & 322만 & $x(x)$ \\
\hline $\begin{array}{l}\text { 5. 스리랑카 } \\
\text { 동부지역 }\end{array}$ & 학교 건축사업 & 2010-2011 & 200만 & $\circ(0)$ \\
\hline $\begin{array}{l}\text { 6. 스리랑카 } \\
\text { 북부지역 }\end{array}$ & 학교 건축사업 & $2011-2014$ & 500 만 & $\circ \quad(0)$ \\
\hline $\begin{array}{l}\text { 7. 필리핀 } \\
\text { 4개주 }\end{array}$ & 미곡종합처리장 건립사업 & 2009-2013 & 1,300만 & $x(0)$ \\
\hline $\begin{array}{l}\text { 8. 아제르바이잔 } \\
\text { 바쿠시 }\end{array}$ & $\begin{array}{l}\text { 지식재산권 관리시스템 } \\
\text { 자동화사업 }\end{array}$ & $2011-2013$ & 420만 & $x(0)$ \\
\hline $\begin{array}{l}\text { 9. 팔레스타인 } \\
\text { 제닌지역 }\end{array}$ & $\begin{array}{l}\text { 기초 보건의료서비스 } \\
\text { 강화사업 }\end{array}$ & 2009-2011 & 300만 & $x(x)$ \\
\hline $\begin{array}{l}\text { 10. 모로코 } \\
\text { 카사블랑카 }\end{array}$ & $\begin{array}{l}\text { 자동차 직업훈련원 } \\
\text { 지원사업 }\end{array}$ & 2010-2013 & $\begin{array}{c}\text { 600만 } \\
(+600 \text { 만)* }\end{array}$ & $\circ(0)$ \\
\hline $\begin{array}{l}\text { 11. 파라과이 } \\
\text { 아순시온 }\end{array}$ & 첨단교통관리체계 구축사업 & 2013-2015 & 549만 & x (보류) \\
\hline 12. 페루 리마 & $\begin{array}{l}\text { 도스데마요 국립병원 } \\
\text { 검진기능 개선사업 }\end{array}$ & 2008-2010 & $\begin{array}{c}\text { 470만 } \\
(+900 \text { 만)* }\end{array}$ & $x(x)$ \\
\hline
\end{tabular}

※ 괄호 안의 금액은 수원국 정부의 출자금 액수임.

출처: 한국국제협력단 (2016a, 2016b)

위의 사업 중에서 범분야로 젠더 이슈를 포함시켜 사업을 진행된 것으로 평가된 4개 개발협력 사례를 좀 더 자세히 살펴보면 다음과 같다.

25) 파라과이 아순시온 첨단교통관리체계 구축사업 종료평가 보고서, p. 140. "TMC 구성인원 13 명 중, 여성은 1 명으로 본 사업관련 여성 참여 비율이 낮으나 성주류화는 본 평가관련 적절한 지표가 아닌 것으로 보여 평가를 보류함." 
〈표 4〉 기획단계에서 젠더를 고려한 개발협력 프로젝트

\begin{tabular}{|c|c|c|c|}
\hline 사업명 & 기획단계 성 주류화 & 성평등 효과 여부 & 미비점/제언/기타 \\
\hline $\begin{array}{c}\text { 방글라데시 치타공 } \\
\text { 직업훈련원 역량강화 } \\
\text { 사업 }\end{array}$ & $\begin{array}{l}\text { - 여성을 위한 봉제와 IT공과 } \\
\text { 개설 } \\
\text { - 여학생을 고려한 화장실 }\end{array}$ & $\begin{array}{l}\text { - 교육기회 제공으로 여성 } \\
\text { 취업기회 확대 } \\
\text { - 여성용 화장실 }\end{array}$ & $\begin{array}{l}\text { - 화장실 수가 학생 수에 비 } \\
\text { 해 부족 } \\
\text { - 다른 편의시설 추가확대 } \\
\text { 필요 } \\
\text { - 한국연수교사 성별 통계 } \\
\text { 없음 }\end{array}$ \\
\hline $\begin{array}{l}\text { 스리랑카 동부지역 } \\
\text { 학교건축사업 }\end{array}$ & - 남녀분리 화장실 & - 남녀분리 화장실 & $\begin{array}{l}\text { - 사업제안서 등 문건에 있 } \\
\text { 지는 않음 }\end{array}$ \\
\hline $\begin{array}{l}\text { 스리랑카 북부지역 } \\
\text { 학교건축사업 }\end{array}$ & $\begin{array}{l}\text { - 남녀 모두에게 균등한 교육 } \\
\text { 기회제공 } \\
\text { • 남녀분리 화장실 }\end{array}$ & $\begin{array}{l}\text { - 여학생의 교육 접근성 향 } \\
\text { 상 } \\
\text { - 남녀분리 화장실 }\end{array}$ & $\begin{array}{l}\text { - 교사숙소 거주 교사 성별 } \\
\text { 정보 없음 }\end{array}$ \\
\hline $\begin{array}{l}\text { 모로코 카사블랑카 } \\
\text { 자동차 직업훈련원 } \\
\text { 지원 사업 }\end{array}$ & $\begin{array}{l}\text { - 여성친화적인 자동화시스템 } \\
\text { 공과 개설 } \\
\text { - 여성친화적 건물설계와 시설 } \\
\text { - 수세식 화장실 } \\
\text { - 안전을 위한 CCTV 설치 }\end{array}$ & $\begin{array}{l}\text { - 여성의 직업훈련 교육기 } \\
\text { 회 확대 } \\
\text { - } 12 \%->20 \% \\
\text { - 졸업생 취업률 여성이 } \\
\quad \text { 더 높음(여성 } 80 \% \text {, 남 } \\
\quad \text { 성 } 74 \%) \\
\text { - 여성을 고려한 편의 및 안 } \\
\text { 전시설 }\end{array}$ & $\begin{array}{l}\text { - 훈련원이 주요 도로에서 } \\
3 \mathrm{~km} \text { 떨어진 외진 곳에 있 } \\
\text { 어 등하교길 안전 주의 필 } \\
\text { 요 }\end{array}$ \\
\hline
\end{tabular}

제I 장

출처: 한국국제협력단 $(2016 \mathrm{~b})$ 의 해당 사업보고서

젠더를 기획단계에서부터 고려했다고 평가된 4개의 사업은 방글라데시와 모로코에서 수행된 직업훈련사업과 스리랑카 2개 지역에서의 학교 건축사업이다. 직업훈련원 지원 사업은 여성에 게 취업훈련의 기회를 제공하여 경제적 역량강화를 하므로 성평등을 위한 주요한 분야이다. 방글라데시 사업의 경우 전통적 여성 직종인 봉제만으로 그치지 않고 정보통신기술 분야를 개설하여, 사업수행 이전보다 누적 여학생 수가 약 30배 증가하였다(한국국제협력단, 2016b: 100). 남성들 직종으로 여겨지는 기계, 산업설비, 전기전자, 자동차 분야 훈련에도 2016년까지 모두 약 100 명의 여학생이 취업훈련을 받았다. 모로코의 경우에도 여학생친화적인 자동화시스 템 공과를 개설한 것 등이 돋보인다. 현존하는 성별 직종 분리 현상을 개선할 수 있는 취업훈련 프로그램을 제공하는 것이 젠더 임금 격차를 줄일 수 있는 길이다.

<표 4>의 4개 사업 모두 여성을 위한 분리된 화장실을 설치하였고, 특히 남녀 화장실의 분리가 법적으로 의무화되지 않은 스리랑카의 상황에서 여성용 화장실을 수세식으로 분리 설치 한 것, 안전을 위해 CCTV를 설치한 것은 성추행 등 폭력의 위협에서 여성을 보호하는 효과가 있다. 
그러나 성 주류화를 위한 보다 적극적인 기획은 보이지 않았다. 스리랑카 학교건축사업의 경우 명확한 기획서 없이 화장실 분리 설치 사실만으로 젠더적 고려가 있는 것으로 결론을 내렸고, 재학생들이나 중도 탈락 학생들의 성별 통계라든가 학생들과의 인터뷰에서도 남녀 학생의 구별이 없었다. 또 교사들을 위한 숙소 이용문제도 남녀별로 어떤 다른 수요나 문제가 있는지 등에 전혀 관심을 기울이지 않았다.

<표 3>의 베트남 상수도 건설사업이나 라오스 문군 사업, 필리핀 미곡처리장 사업 등의 경우 사업기획이나 집행단계에서 성평등에 대한 고려가 전혀 없었다고 평가되었다. 평가자들은 범분야 이슈가 간과되지 않고 정착되도록 하기 위한 노력이 필요하며, 향후에는 사업의 타당성 조사나 예비조사 시 성평등을 비롯한 범분야 이슈를 사업 수립과 집행, 모니터링에 포함해야 한다고 제안하였다. 그러나 왜 고려가 안 되었는지에 대한 원인분석은 없었다.

\section{4. 결론에 대신하여: 앞으로의 과제}

$\mathrm{KOICA}$ 사업평가보고서를 통해 우리가 확실히 알 수 있는 것은 국제개발협력에서 범분야 이슈로서 성 주류화는 아직 자리를 잡지 못했다는 것이다. 개발협력을 요청하는 수원국뿐만 아니라 공여자 측에서도 사업의 기획단계에서부터 집행, 평가까지 젠더 문제를 고려하는 것이 아직 체질화되지 못한 듯하다. 또 외부 평가자가 범분야를 평가에 포함하지 않은 경우도 상당히 있었고, 성 주류화 문제를 당연히 적용해야 하는 것으로 본문에 기술한 경우에도 이를 결론이나 제언에 중요한 사안으로 포함시키지 않은 경우도 많았다. 아울러 젠더적 관점을 적용했을 때 좀 더 다양하고 정밀한 분석과 제안이 가능한 경우에도 그렇지 못해서 아쉬운 면도 있었다.

젠더를 기반으로 하는 국제개발협력이 이루어지기 위해서는 다음의 두 가지가 꼭 필요하다고 본다. 첫째는 제도적으로 현재의 평가 시스템을 수정하여 범분야도 평가점수에 반영해야 한다. 지금의 시스템은 범분야가 평가 기준에는 들어가 있지만, 그 준수 여부가 점수로 환산이 되지는 않는다. 따라서 현재의 성 주류화에 대한 의지는 꼭 해야 하는 것이라기보다는 권장하는 수준에 불과하다. 젠더를 고려하면 좋은 인상을 주기는 하지만, 그것이 점수로 확실하게 연결되지 않는 다. 젠더 관점을 잊어버리거나, 또는 잘 이해를 못 해서 적용을 안 시키더라도 아무 불이익도 없다. 젠더 관점 도입여부를 평가에서 점수화해야 한다.

둘째는 성 주류화를 위한 인력의 확보와 운용이다. SDGs 이행의 모든 분야에 성평등과 성 주류화가 의무화되었다. 이를 적극적으로 이행하기 위해서는 이를 담당할 인력이 필요하다. 실제 사업기획단계에서부터 젠더 전문관이 결합하여 젠더에 기반한 개발협력사업이 될 수 있도 
록 해야 한다. 당장 인력이 모자라면 젠더 이슈의 전문가 그룹을 모아 인력을 어떻게 충원할 것인가를 논의하는 것에서부터 시작하는 것이 필요하다.

성평등의 문제는 인류의 절반의 인권문제이다. 그리고 또한 그 절반의 인구가 어떻게 하면

역량을 강화하여 자신과 다른 모두의 삶이 더 나아질 수 있도록 변화를 이끄는 주역이 되게 하는가의 문제이기도 하다. 


\section{참고문헌}

강선미. 2016. “제6장 젠더”, 『국제개발협력 심화편』. 성남.한국국제협력단.

여성가족부. 2017. "UN 안보리결의 1325호 제2기 국가행동계획 공청회" (2017. 11. 22. 한국 여성정책연구원 국제회의장에서 개최).

$\mathrm{UN}$ 경제사회문화적 권리 위원회(CESCR). 2017. "일반논평 제24호: 기업활동과 관련하여 경제적, 사회적, 문화적 권리에 관한 국제규약에 따른 국가의무."국가인권위원회 번역 (2017.08.10. 배포).

한국국제협력단. 2016a. ${ }^{\mathrm{KOICA}} 2016$ 평가연보』. 성남. 한국국제협력단. . 2016b. 2016년도 KOICA 프로젝트 종료평가 및 사후평가보고서』. 성남. 한국국제협력단. (http://www.koica.go.kr/download/2016/2016_annual_kr.pdf) (접속일: 2017.11.26.).

2016c.『스리랑카 동부·북부지역 학교 건축사업 종료 및 사후평가 보고서』. 성남. 한국국제협력단. (http://tmslib.koica.go.kr/search/media/img/CAT00000004 0835?metsno=000000015190\&fileid=M000000015190_FILE000001) (접속일: 2017.11.26.).

2016d.『파라과이 아순시온 첨단교통관리체계 구축사업 종료평가 보고서』. 성남: 한국국제협력단. (http://tmslib.koica.go.kr/search/detail/CATTOT0000000 41018) (접속일: 2017.11.26.).

2016e. 『라오스 문군 관개용 댐 및 수로건설사업 사후평가 보고서』. 성남. 한국국제협력단. (http://tmslib.koica.go.kr/search/detail/CATTOT0000000 40836) (접속일: 2017.11.26.).

2016f.『모로코 카사블랑카 자동차 직업훈련원 지원 사업 사후평가 보고서』. 성남. 한국국제협력단. (http://tmslib.koica.go.kr/search/detail/CATTOT0000000 40833) (접속일: 2017.11.26.).

2016g. 『방글라데시 치타공 직업훈련원 역량강화 사업 사후평가 보고서』. 성남: 한국국제협력단. (http://tmslib.koica.go.kr/search/detail/CATTOT0000000 40834) (접속일: 2017.11.26.).

2016h. 『베트남 부온호현 상수도시설 건설사업 사후평가 보고서』. 성남. 한국국제협력단. (http://tmslib.koica.go.kr/search/detail/CATTOT0000000 40838) (접속일: 2017.11.26.).

2016i. 『아제르바이잔 지식재산권 관리시스템 자동화사업 사후평가 보고서』. 
성남. 한국국제협력단. (http://tmslib.koica.go.kr/search/detail/CATTOT 000000040 854) (접속일: 2017.11.26.).

2016j. 『필레스타인 제닌지역 기초보건의료서비스 강화사업 사후평가 보고서』. 성남: 한국국제협력단. (http://tmslib.koica.go.kr/search/detail/CATTOT 0000000 40840) (접속일: 2017.11.26.).

2016k. 『페루 리마 도스데마요 국립병원 검진기능 개선사업 사후평가 보고서』.

성남: 한국국제협력단. (http://tmslib.koica.go.kr/search/detail/CATTOT0000000 40839) (접속일: 2017.11.26.)

20161. 필리핀 4개주 미곡종합처리장 건립사업 사후평가 보고서』. 성남:

한국국제협력단. (http://tmslib.koica.go.kr/search/detail/CATTOT000000040853)

(접속일: 2017.11.26.).

한국여성개발원. 1995. 『제 4 차 세계여성회의 북경선언·행동강령』. 서울: 한국여성개발원.

Boserup, Ester. 1970. Women's Role in Economic Development, London: George Allen \& Unwin.

Gayle Rubin. 1975. "The Traffic in Women: Notes on the 'Political Economy' of Sex”, in Rayna Reiter, ed., Toward an Anthropology of Women, New York: Monthly Review Press.

Lourdes Beneria and Gita Sen. 1981. “Accumulation, Reproduction and Women's Role in Economic Development: Boserup Revisited," in Signs, Vol. 7, No. 2, Development and the Sexual Division of Labor (Winter, 1981). pp.279-298. OECD DAC. 2016. "History of the 0.7\% ODA Target,"available at https://www.oecd.org/dac/stats/ODA-history-of-the-0-7-target.pdf （접속일: 2017.11.24.).

OHCHR. 2007. Integrating the human rights of women throughout the United Nations system (Resolution 6/30). Geneva: United Nations Human Rights Council. UN. 1993. Vienna Declaration and Program of Action., adopted by the World Conference on Human Rights in Vienna on 25 June 1993. http://www.ohchr.org/ EN/ProfessionalInterest/Pages/Vienna.aspx (접속일: 2017.11.24.).

. 1994. Programme of Action of the International Conference on Population and Development. Report of the International Conference on Population and Development (A/CONF.171/13). http://www.un.org/popin/icpd/conference/offeng/ poa.html (접속일: 2017.11.24.). 
. 1996. Report of the Fourth World Conference on Women. (A/CONF. 177/20/Rev.1). New York: United Nations.

. 2002. Gender Mainstreaming: An Overview. New York: United Nations. . 2006. Delivering as One: Report of the High-level Panel on United Nations

System-wide Coherence in the area of development, humanitarian assistance and the environment.(A/61/583). New York: United Nations.

- 2015. Transforming Our World: The 2030 Agenda for Sustainable Development. New York: United Nations.

UN CSW. 2014. "Challenges and achievements in the implementation of the Millennium Development Goals for women and girls: Moderator's summary." (E/CN.6/2014/INF/6). New York: United Nations Commission on the Status of Women.

UN CEDAW. 2013. General recommendation No. 30 on women in conflict prevention, conflict and post-conflict situations (CEDAW/C/GC/30). file://C:/Users/MASTER/ Downloads/N1354331\%20(2).pdf (접속일: 2017.11.24.). . 2017. General comment No. 24 (2017) on State obligations under the International Covenant on Economic, Social and Cultural Rights in the context of business activities.. E/C.12/GC/24. file://C:/Users/MASTER/Downloads/ G1723717\%20(5).pdf (접속일: 2017.11.24.).

2017. Concluding observations on the sixth periodic report of the Netherlands. (E/C.12/NLD/CO/6). file://C:/Users/MASTER/Downloads/ G1718296\%20(1).pdf (접속일: 2017.11.24.).

. 2017. Concluding observations on the fourth periodic report of the Republic of Korea. (E/C.12/KOR/CO/4). file:///C:/Users/MASTER/ Downloads/ G1732316\%20(1).pdf (접속일: 2017.11.24.).

United Nations Security Council. 2000. Resolution 1325. Adopted by the Security Council at its 4213th meeting, on 31 October 2000. S/RES/1325(2000). https://documents-dds-ny.un.org/doc/UNDOC/GEN/N00/720/18/PDF/N00720 18.pdf?OpenElement (접속일: 2017.11.24.).

World Bank. 2012. World Development Report 2012: Gender Equality and Development. Washington D.C.: World Bank. 